\title{
Romancing the Stone Age: John Updike's "Wife-Wooing" and the Naturally Occurring Nuclear Family
}

Sue Norton

Technological University Dublin, susan.norton@tudublin.ie

Follow this and additional works at: https://arrow.tudublin.ie/aaschlanart

Part of the English Language and Literature Commons

\section{Recommended Citation}

Norton, S. (2013) Romancing the Stone Age: John Updike's "Wife-Wooing" and the Naturally Occurring Nuclear Family. Explicator, Vol. 71, 3 2013. doi:10.1080/00144940.2013.811399

This Article is brought to you for free and open access by the Languages at ARROW@TU Dublin. It has been accepted for inclusion in Articles by an authorized administrator of ARROW@TU Dublin. For more information, please contact arrow.admin@tudublin.ie, aisling.coyne@tudublin.ie,gerard.connolly@tudublin.ie. 


\section{Romancing the Stone Age: John Updike's "Wife-Wooing" and the Naturally Occurring Nuclear Family}

\begin{tabular}{|r|l|}
\hline Journal: & The Explicator \\
\hline Manuscript ID: & $08-12-178$ \\
\hline mstype: & Manuscript \\
\hline Specialty Area: & 20th century < American Literature \\
\hline & \\
\end{tabular}

\footnotetext{
SCHOLARONE ${ }^{\text {M }}$

Manuscripts
} 


\author{
Romancing the Stone Age: \\ John Updike's 'Wife-Wooing' and the Naturally Occurring Nuclear Family
}

John Updike's 1960 story "Wife-Wooing," is a short tale of married life that connects mid-twentieth century suburbia to a pre-historic past. Though history demonstrates that kinship arrangements and have varied over time and place, "WifeWooing" powerfully impresses us with the idea that the nuclear family is not only traditional, but natural. Despite its ironic pretensions, the story has a decidedly archetypal quality. It provokes in the reader's imagination the appearance that things are now as they always have been.

At just a few pages long, "Wife-Wooing" illustrates the compelling hold a vision of the past can have on a version of the present. It seemingly brings millennia of human interaction to bear upon the uneventful evening of a 1960s American family grouped around a take-out meal of hamburgers and French fries. The scene is largely one of domestic and marital harmony in which husband and wife tend lovingly to their offspring, feeding them, talking to them, and tucking them into bed. Updike powerfully invokes a distant, even stone age past through his use of cave-man imagery. The family "eats meat," meat which the husband "wrested warm from the raw hands of the hamburger girl in the diner a mile away" (1066). Together mother, father and children sit huddled around their fireplace on a winter's night taking shelter from the cold. The husband, who narrates, refers to his progeny as "the girl" and "the boy." He relates how, on their honeymoon, he and his wife "spilled blood," and he anticipates a sexual encounter with her that evening. By creating this elemental world of basics -- food, fire, shelter, sex -- Updike strongly hints at an overall naturalness to the scene. Lines such as the following reinforce this impression: "As the flame on 
the circular wick flickered, the wide soft star of interlocked penumbrae moved and waved as if it were printed on a silk cloth being gently tugged or slowly blown. Its color soft blurred blood. We pay dear in blood for our peaceful homes" (1068).

Such elemental, primal aspects of the story serve well to support -- that is, lend naturalness to -- the modern aspects of the story. That the husband leaves hearth and home the next morning to go to work seems logically (i.e. naturally) to derive from his maleness:

\begin{abstract}
The man, he arrows off to work, jousting for right-of-way, veering on the thin hard edge of the legal speed limit. Out of domestic muddle, softness, pallor, flaccidity: into the city. Stone is his province. The winning coin. The maneuvering of abstractions. Making heartless things run. Oh the inanimate, adamant joys of job! (1068)
\end{abstract}

The careful syntax in the phrase "of job," and use of the word "stone," hearken us back to the semi-mythic caveman and imply a biologic essentialism to the husband's twentieth-century work-a-day world. ${ }^{1}$

Likewise, as the husband ruminates on the linguistic properties of the word "woman," the physicality of femaleness seemingly becomes the very source of the wife's position in the family as homemaker:

\begin{abstract}
What soul took thought and knew that adding "wo" to man would make a woman? The difference exactly. The wide w, the receptive o. Womb. In our crescent the children for all their size seem to come out of you toward me, wet fingers and eyes, tinted bronze. Three children, five persons,
\end{abstract}


seven years. Seven years since I wed wide warm woman, white-thighed.

Wooed and wed. Wife. (1066)

Even the words "crescent," referring to the family's semicircle around the fire, and "bronze," referring to their glow in the light of the flames, provoke associations with ancestral humanity. Thus the husband, wife, and children of "Wife-Wooing" take on the status of prototypes in much the same way that Robert Frost's fencefavouring farmer in "Mending Wall" resembles popular images of primordial man.

\author{
I see him there \\ Bringing a stone grasped firmly by the top \\ In each hand, like an old-stone savage armed. \\ He moves in darkness as it seems to me, \\ Not of woods only and the shade of trees. \\ He will not go behind his father's saying, \\ And he likes having thought of it so well \\ He says again, 'Good fences make good neighbors.' (Frost 1088)
}

As with Frost's poem, the reader of Updike's story is left with the impression that nothing short of atavistic instinct is the guiding force behind our assumed roles and our adopted lifestyles. In "Wife-Wooing," the gendered division of labour (indeed labour itself) ${ }^{2}$, and the insular characteristics of family, appear profoundly natural. In its unabashed romancing of the stone-age, we forget entirely that "WifeWooing," in its invocation of the pre-historic campfire especially, is merely rekindling old stereotypes: the hunter and the gatherer, the procurer and the provender. 
In the context of a sexually tumultuous 1960s America, this re-kindling of stereotypes serves particular, conservative ideological purposes. Yet it does so in a way that allows for the espousal of marital equality and the donning of, in the famous 1960s phrase, "separate but equal" stereotypes. While the husband and wife of "Wife-Wooing" may blissfully assume their conventionally gendered roles, they are also quite blissfully equal. We find no subservience here, no psychological domination. We learn, in fact, that the wife is reading a book about Richard Nixon, thereby demonstrating to us that her housewifery is not devoid of ideas or intellectualism. She and her husband may have separates roles, but they are equals.

Thus, in "Wife-Wooing, Updike invokes stereotypes and simultaneously revises them by making them more modern. In so doing, he makes these stereotypes more palatable for readers of the day. The story reasserts the nuclear family as the form for all seasons, suggesting a primal essentialism to familiar gender roles.

Notes:

${ }^{1}$ The notion of man as an arrow and woman as a bow is a metaphor that Sylvia Plath also used in The Bell Jar (1963), in which she wrote "what man is, is an arrow that shoots into the future, and what a woman is, is the place the arrow shoots off from" (58). This is the homespun wisdom of Mrs. Willard, who is constructed in the novel as a guarantor and protector of patriarchal nuclearity. Ester, the central character, detests Mrs. Willard's metaphor of the arrow, and declares that she "wants to shoot off in all directions myself, like the colored arrows from a $4^{\text {th }}$ of July Rocket" (68). Where The Bell Jar presents a feminist critique of the notion of arrow and bow implicit in the patriarchal ideology of marriage, "Wife-Wooing" uses the metaphor to represent its naturalisation. Sylvia Plath, The Bell Jar (New York: Bantam Books, 1986).

${ }^{2}$ Roland Barthes also remarks upon the seemingly "essential" quality of work in his essay "The Great Family of Man" (1953) in which he argues that family structure, dynamics, and organization, are, despite any appearance of "universality," highly subject to the "determining weight of History" (101). See Roland Barthes, Mythologies (London: Vintage, 1993). 
Bibliography:

Frost, Robert. "Mending Wall." The Norton Anthology of American Literature. Ed. Nina Baym, et. al. 4th ed. Vol. 2. New York: Norton, 1994.

Updike, John. "Wife-Wooing." Classic Short Fiction. Ed. Charles H. Bohner. New Jersey: Prentice-Hall, 1986. 1066-1068. 